\title{
The Relationship between Decision Making Styles and Leadership Styles among Public Schools Principals
}

\author{
Aieman Ahmad Al-Omari ${ }^{1}$ \\ 1 Associate Professor, Higher Education Administration, Faculty of Educational Sciences, Hashemite University, \\ Zarqa, Jordan
}

Correspondence: Aieman Ahmad AL-OMARI, Faculty of Educational Sciences, Hashemite University, Zarqa 13133, P.O. Box 330206, Jordan. Tel: 962-796-618-374. E-mail: aieman66@hotmail.com

Received: March 31, 2013 Accepted: May 3, 2013 Online Published: June 24, 2013

doi:10.5539/ies.v6n7p100 URL: http://dx.doi.org/10.5539/ies.v6n7p100

\begin{abstract}
The present study examined the relationships between leadership styles and decision-making styles among public schools principals. A total of 108 principals returned questionnaires from Russaifa Education District in Jordan. The Decision Style Inventory and the Administrative Styles Questionnaire were used in this study. "Directive decision making style" was predominant among school principals,. Leadership style $(5,5)$ "Constituency-Centered Administration" was predominant among school principals. The results revealed that no significant correlation exists between decision making styles and leadership styles of school principals. Upon the research findings, some recommendations were recommended.
\end{abstract}

Keywords: decision making styles, leadership styles, school principals, Jordan

\section{Introduction}

Every day people are faced with the need to make decisions. Decision-making, therefore, encompasses an array of processes some of which have been the subject of extensive investigations. One of the key functions of leaders is to set long-term goals for their organizations. Studies of decision making have revealed numerous versions of the decision-making process that depend both on internal factors and the organization's context. Examples of such studies are the effect of economic factors on decision-making (Starmer, 2000; Tversky \& Thaler, 1990), the effects of political factors (Bianco, 1984; Dorff \& Steiner, 1981; Hanson, 1970), the effects of social factors (Myers, 2000; Sturn, 1999; Prechel, 1994), as well as the effect of psychological factors (Ravlin and Meglino, 1987; Rowe, Boulgarides, McGrath, 1984; Gelatt, 1962).

The present study focuses on the relationship between decision-making styles and leadership styles in Jordanian public schools, at Russaifa Education District in Jordan for the second semester of academic year 2006/ 2007.

The word decision has been defined as "an answer to some question, a choice between two or more alternatives" (Rowe et al, 1984, p. 3). Gelatt (1962) suggested that making a decision is a process that includes several components such as estimating the outcomes, understanding these possible outcomes, choosing an outcome, and finally taking the appropriate action. According to Krumboltz and Hamel (1977) making a decision a series of steps, namely, defining the problem, creating a plan of action, examining possible alternatives and outcomes, and starting the action. Ravlin and Meglino (1987) claimed that making decisions is influenced by the individual's personal duties and values. Alker, Rao and Hughes (1972) argued that process of making decisions is based on the available information.

Leadership is a complicated phenomenon and can be defined in a variety of different ways. "Leadership is a relationship between those who aspire to lead and those who choose to follow" (Kouzes \& Posner, 2002). "Leadership is the ability to step outside the culture... to start evolutionary change processes that are more adaptive" (Schein, 1992). "Leadership is the process of making sense of what people are doing together so that people will understand and be committed" (Drath \& Palus, 1994). "Leadership is the ability of developing and communicating a vision to a group of people that will make that vision true" (Valenzuela, 2007).

Pitz and Harren (1980) pointed out that a decision maker faces at least two alternatives evaluated according to his or her values and preferences. Phillips (1997) argued that the process of making a decision involves five stages: (a) identifying all the existing alternatives; (b) valuing the alternatives according to preferences, and their 
potential outcomes; (c) assembling the information; (d) swapping between preferences and outcomes; and (e) selecting the most favorable alternative yields to the decision. Rowe et al. (1984) suggested that decision-making is a process that includes the element of evaluating the merit of the potential consequences. They also proposed a five stages model for the decision-making process, as follow: (a) defining the problem, which is the most difficult and critical one, because it requires identifying the right problem; (b) finding and analyzing alternatives solutions; (c) implementing the decision, which is carried out bearing in mind the strategy needed, the time parameters, the required efforts, and the available resources; (d) achieving results, which involves evaluating the outcome, making alteration, and continuing the action; and (e) decision consequences, which involves considering the long term effect, in a subsequent paper. As a result of these five-stages analysis, Rowe and Mason (1987), referred to the decision making process as a cognitive process comprised of five elements: (1) the stimulus, which arouses the decision maker; (2) the manner in which the individual respond to the stimulus; (3) the thinking about the problem; (4) implementing and executing the decision; and (5) determining the effectiveness of the decision whether or not it helps achieving the desired goals.

Thunholm (2004) investigated the relationship between decision-making styles, self-esteem and self-regulation. In measuring decision making style, Thunholm used the General Decision Making Style (GDMS) test developed by Scott and Bruce (1995). These authors identified four decision styles: (a) rational, (b) intuitive, (c) dependent, and (d) avoidant. The first, rational style refers to searching for information and seeking alternatives. The second, intuitive style characterizes attention to details and the tendency to rely on feelings. The third, dependent style is characterized by the search for suggestion and supervision before making a decision. Finally, the last, avoidant style refers to the tendency to avoid from making decisions. Thunholm (2004) suggested that decision-making style is not a skill but rather a process that involves self-evaluation as well as the capability to initiate and maintain self regulation.

Rowe et al. (1984) proposed the term decision style, which reflects the way a person uses information to reach a decision. Decision style focuses the attention to the way one uses information and derives meaning from it. People may be classified in two opposing end of a continuum. One end represents those who use the least amount of data and thus who save time. The other end represents those who use the greatest amount of data and try to achieve the best possible solution without any concern for time.

Decision style has been conceptualized as a value orientation/personal, value that forms four basic styles depicting four combinations of styles: (a) directive, (b) analytical, (c) conceptual, and (d) behavioral. These four styles are the Cognitive Complexity Model developed by Rowe and Mason (1987). The Cognitive Complexity Model represents an attempt to characterize the way people arrive at decisions. It uses knowledge gleaned from social psychology, cognitive psychology, structural engineering, organization behavior, and information systems. The four styles of the Cognitive Complexity Model are as follows: (1) The Directive style, that characterized by low tolerance for ambiguity and low cognitive complexity. The orientation is focused on task and technical concerns. (2) The Analytical Style, that characterized by high tolerance for ambiguity. (3) The Conceptual style, that characterized by high tolerance for ambiguity and high cognitive complexity. (4) The Behavioral style, that characterized by low tolerance for ambiguity and low cognitive complexity (Boulgarides \& Cohen, 2001; Connor \& Becker, 2003; Rowe \& Davis, 1996; Rowe \& Mason, 1987).

According to Rowe and Boulgarides (1992), identifying one's decision style may predict behavior such as reactions to stress, motivation, problem solving abilities, and general manner of thinking. The decision profile of any given individual reflects a combination of all four styles. It may be characterized as either one dominant style or as a balanced profile with all four at a similar strength.

Leadership styles have been examined and re-examined by observers of management for many years. As a result, a number of theories have evolved. Debate between those who contend that there is one best style of leadership and those who contend that situations call for different styles has continued for many years among theorists and researchers (Burke, 1982).

Darwazeh (2003) results of his study showed that the percentage average of taking decisions by the principals was $83.2 \%$. The principals' decisions were taken most in the learners and teachers domains, whereas the decisions related to school's environment and the curriculum domains were the least. The point was further debated that the dominance of one style or the other depends on the specific situation (situational/ contingency leadership). This approach was advanced in the model of Hersey and Blanchard (1982) and Fiedler (1967). The normative model of leadership contends that there is one best form of leadership which involves a simultaneous high concern for production and concern for people. Blake and Mouton (1978) define this model. This study adopts Blake \& Mouton (1985) model, Managerial Grid. The Grid measures two dimensions of leadership: 
concern for production and concern for people. These two variables are plotted along two axes. The two dimensions are independent of each other, resulting in the leader being high or low on both axes, or high on one and low on the other.

The Blake Mouton Managerial Grid, through its accompanying assessment instruments, identifies five major or dominant grid styles: 1, 1 Caretaker Administration; 1, 9 Comfortable and Pleasant Administration; 9, 1 Authority-Obedience Administration; 9, 9 Team Administration; and 5, 5 Constituency-Centered Administration. These five styles represent the basic styles and are typical of most administrators.

However, several recognize grid combinations have been recognized for use as well (Blake \& Mouton, 1985; Blake, Mouton \& Williams, 1981). One combination approach cited in the Academic Administrator Grid is the 9+9 approach to administration which is a combination of 9,1 and 1,9 styles. This style is commonly referred to as Paternalism/ Maternalism Administration, and is very important to academic administration (Blake et al., 1981).

\section{Purpose of the Study}

The purpose of this study is to investigate the relationship between decision making styles and leadership styles of principals in Russaifa education district. The following research questions were formulated to guide the research:

Question One: Does any leadership style predominant among school principals?

Question Two: Does any Decision making style predominant among school principals?

Question Three: Is there a significant relationship between decision making styles and leadership styles among school principals?

\section{Methodology}

\subsection{Population and Sample of the Study}

The population of the study consisted of 150 principals at Russaifa Education District in Jordan for the second semester of academic year 2006/2007. All 150 principals are selected as a sample of the study. A total of 108 principals ( 60 male and 48 female) returned questionnaires.

\subsection{Instruments of the Study}

\subsubsection{Decision Style Inventory (DSI)}

Decision Style Inventory (DSI), (Rowe, and Mason (1987) (see Appendix B) developed the Decision Style Inventory (DSI) as an instrument assessing one's decision making style. The instrument identifies four basic styles: Analytical style, Conceptual style, Behavioral Style, and Directive style. Rowe and Mason (1987) reported that over 10,000 individuals took the inventory. Reportedly it has shown excellent split-half and test-retest reliability as well as validity measured by correlations with other test instruments.

The researcher in this study translated the English version to Arabic. The Arabic version of the questionnaire was backward translated into English. The researcher compared the original English questionnaire and the back-translated questionnaire. Twelve specialists in the field of educational administration assessed the validity of the questionnaire. After minor adjustments, the meanings of the two questionnaires matched. However, the results of a pilot study of 20 participants different than that of the study but withdrawn from the same population demonstrated that the reliability scores for the Analytical style, Conceptual style, Behavioral Style, and Directive style 1 dimensions were $.87, .78, .85$ and .79 , respectively (based on Cronbach's coefficient alpha).

- The Directive style. This style is characterized by low tolerance for ambiguity and low cognitive complexity. The orientation is focused on task and technical concerns. Persons characterized with this style are described as practical, autocratic, rigid, impersonal, and have a strong desire for power and control. They have a need for speed, efficient and satisfactory solutions because they have limited information and few alternatives. People with this style show a preference for structure and specific information and facts, which are usually given in a verbal way. This style is marked by aggressiveness and tight control, and a need for security and status (Connor \& Becker, 2003; Bou1garides \& Cohen, 2001; Rowe \& Davis, 1996; Rowe \& Mason, 1987). The directive style is analogous to the sensing-thinking type, in that such individuals focus on working toward a signal goal, are domineering in decision-making, and prefer precisely organized methods of working.

- The Analytical Style. This style is characterized by high tolerance for ambiguity. The orientation is focused on task and technical concerns involving a logical approach. Persons with this style are typically intellectual, have a need for control and position, are too dogmatic, and can be impersonal. Their personality is characterized by 
more cognitive complexity, meaning that they tend to look for much information and from several alternatives. Such individuals are able to deal with complex and new situations; they analyze and examine details, desire to achieve the best possible solutions and are able to predict outcomes (Connor \& Becker, 2003; Bou1garides \& Cohen, 2001; Rowe \& Davis, 1996; Rowe \& Mason, 1987). The analytical style is parallel to both the intuiting-thinking and sensing-thinking types, in that decision-making remains unemotional and relies upon detailed models, measurement and plans.

- The Conceptual style. This style is characterized by high tolerance for ambiguity and high cognitive complexity. This orientation is connected to people and their social concerns. Such persons are creative and tend to take risks in finding answers. They have the ability to understand complex relationships. Intuition guides their search for information and examinations of multiple sources and alternatives. Persons characterized with this style are people-oriented, open and from truthful relationships with others. Such individuals do not look for control and power rather they like to share such things with others. They are very personable, flexible, and tend to be idealistic, having a strong emphasis on values and ethics (Connor \& Becker, 2003; Boulgarides \& Cohen, 2001; Rowe \& Davis, 1996; Rowe \& Mason, 1987). The conceptual style is comparable to the intuiting feeling and intuiting-thinking types, in those persons rely on intuition, consider things in the long-term, and make decisions in a decentralized manner.

- The Behavioral style. This style is characterized by low tolerance for ambiguity and low cognitive complexity. The orientation of this style is toward people and social concerns. Such people are supportive and friendly. They have open communication and are interactive, interested in others, open to suggestions, warm, and empathic. They enjoy being surrounded by people, and tend to avoid conflicts. Their focus is on short-run problems and they have difficulties making difficult decisions (Connor \& Becker, 2003; Boulgarides \& Cohen, 2001; Rowe \& Davis, 1996; Rowe \& Mason, 1987). The behavioral style is most similar to the sensing-feeling type, in that this decision-making style relies upon group involvement, from the knowledge of expert in planning to the acceptance of a decision by other involved.

The inventory contains 20 items organized in five columns. The first column lists the item (statements). For example: "My prime objective is to ...", or "When I am not sure about what to do 1. .. ". Each of the remaining four columns provides four possible responses to the item (statement). For instance, to the item "When I am not sure about what to do, 1...": The four possible responses are: "Rely on intuition", or "Search for facts" or "Look for a possible compromise", or "Wait before making a decision". These responses reflect the respondents' preferences. Each of these responses is assigned a value (score), e.g., I = least preferred, $2=$ considered on occasion, $4=$ considered often, $8=$ most preferred.

Once all responses have been ranked, the scores in each column are totaled. The total scores obtained on the second column represent the directive style. The total scores obtained on the third column represent the analytical style. The total scores obtained on the fourth column represent the conceptual style, and the total scores obtained on the fifth column five represent the behavioral style. There is no time limit for completing the inventory, and there are no rights or wrongs answers.

\subsubsection{The Administrative Styles Questionnaire}

The researcher in this study used the Arabic version of The Administrative Styles Questionnaire (ASQ), that translated and developed by Al-Omari, Shdeifat, and Abu-naba' (2008) which is based on the Managerial Grid concept of Blake and Mouton (1985) and the Academic Administrator Grid concept of Blake et al (1981). Chronbach coefficient alpha estimates of reliability that done by Al-Omari, Shdeifat, and Abu-naba' (2008) was suitable for this study, .85 for Caretaker Administration, .88 for Authority-Obedience Administration, .73 Comfortable and Pleasant Administration, .87 Consistency-Centered Administration, .79 Team Administration, and .84 for Paternalism/ Materialism Administration.

The Administrator Grid is represented as a grid with concern for production as the $\mathrm{X}$-axis and concern for people as the Y-axis; each axis ranges from 1 (Low) to 9 (High). The Administrative Styles Questionnaire was composed of 36 statements: six statements relating to each of the six areas on leadership behavior: Caretaker Administration $(1,1)$ : Little concern for institutional performance characterizes this style, and low involvement in exercising power and authority is typical of this leader. Because of a lack leadership, subordinates involvement is likely to be low. Questions 2, 12, 13, 24, 28, and 34 represent this style designation. Authority-Obedience Administration $(9,1)$ : This administration has a high concern for institutional performance yet a low concern for people. The major trust is to get results, exercise power and authority in a unilateral way, and extract obedience from subordinates. Questions 3, 8, 18, 19, 26, and 33 represent this designation. Comfortable and Pleasant Administration (1,9): Institutional performance is low, and concern for people is high 
in this orientation. The general belief is that when people are happy, results will take care of themselves and that there will be no need for supervision. Questions 1, 11, 15, 21, 29, and 36 represent this designation. Constituency-Centered Administration $(5,5)$ : The emphasis in this orientation is on moderate institutional performance coupled with moderate concern for people. There is a balance between results and people, so that neither dominates. This administration attempts to gain acceptable results by doing whatever is expected by the superior and simultaneously avoiding actions that lead to criticism. Questions 4, 19, 17, 20, 30, and 32 represent this designation. Team Administration $(9,9)$ : This orientation involves integration of concern for institutional performance with simultaneously high concern for people. Subordinates are encouraged to achieve the highest possible performance in terms of quality, quantity, and personal satisfaction. Involvement is generated in people who are able to mesh their individual efforts for the accomplishment of meaningful goals that are both sound and creative. Questions 5, 9, 16, 22, 27, and 31 represent this designation. And Paternalism/ Materialism Administration (9+9): This orientation emphasizes a 9, 1 concern for performance coupled with a 1,9 motivated approval-giving for compliance. Control of subordinates is maintained by creating a relationship of obligation in such a way as to gain the warmth and affection of subordinates. Questions 6, 7, 14, 23, 25, and 35 on the ASQ reflect the $9+9$ orientation.

Scores for the Administrative Styles Questionnaire were derived by adding the weighted ranks for each statement. Each of the six statements on the six areas of leadership behaviors represents a Grid style designation. Columns are summed and total scores are derived for each of the grid styles. The column with the highest score represents the dominant leadership style. The statements have been randomly placed and are in no particular order. The use of a scoring key shows which statements are 1,$1 ; 9,1 ; 1,9 ; 5,5 ; 9,9$; and 9+9.

\section{Results}

\subsection{Question One: Does any Leadership Style Predominant among School Principals?}

The result in Table 1 shows that leadership style $(5,5)$ Constituency-Centered Administration was predominant among school principals, with mean score 24.25 (SD, 2.57).

Table 1. Means and standard deviation on leadership styles

\begin{tabular}{lccc}
\hline Leadership styles & $\mathrm{N}$ & Mean & Std. Deviation \\
\hline 1, 1: Caretaker Administration & 108 & 21.45 & 2.72 \\
9, 1: Authority-Obedience Administration & 108 & 21.55 & 2.24 \\
1, 9: Comfortable and Pleasant Administration & 108 & 19.88 & 2.78 \\
5, 5: Constituency-Centered Administration & 108 & 24.25 & 2.57 \\
9, 9: Team Administration & 108 & 21.48 & 2.51 \\
9+9: Paternalism/ Materialism Administration & 108 & 23.48 & 2.93 \\
\hline
\end{tabular}

\subsection{Question Two: Does any Decision Making Style Predominant among School Principals?}

The result in Table 2 shows that directive decision making style was predominant among school principals, with mean score 60.37 (SD, 31.82).

Table 2. Means and Standard Deviation on Decision making styles

\begin{tabular}{lccc}
\hline Decision making styles & $\mathrm{N}$ & Mean & Std. Deviation \\
\hline Directive & 108 & 60.37 & 31.82 \\
Analytical & 108 & 41.66 & 22.27 \\
Conceptual & 108 & 24.07 & 8.09 \\
Behavioral & 108 & 33.88 & 8.06 \\
\hline
\end{tabular}




\subsection{Question Three: Is There a Significant Relationship between Decision Making Styles and Leadership Styles among School Principals?}

Table 3 shows the results of the Pearson product moment correlation for the relationship between each of the decision-making styles and leadership styles. The determination of ones' decision style was based on the highest scores obtained on one of the four columns.

Table 3. Pearson correlation analysis between the decision-making styles and the leadership styles

\begin{tabular}{lcccc}
\hline Leadership Styles & \multicolumn{4}{c}{ Decision Styles } \\
\cline { 2 - 5 } & Analytical & Conceptual & Directive & Behavioral \\
\hline 1, 1: Caretaker Administration & .142 & -.139 & -.102 & -.077 \\
9, 1: Authority-Obedience Administration & .139 & -.123 & -.084 & -.125 \\
1, 9: Comfortable and Pleasant Administration & .160 & -.165 & -.046 & -.130 \\
5, 5: Constituency-Centered Administration & -.033 & .079 & -.083 & -.005 \\
9, 9: Team Administration & .173 & -.155 & -.171 & -.084 \\
9+9: Paternalism/ Materialism Administration & -.035 & .051 & -.085 & .083 \\
\hline
\end{tabular}

In the six leadership styles and four decision making styles, six correlational coefficients with an alpha level of .05 were computed. To control for type I error across the six correlations, the Bonferroni Correction with a p-value of less than $.01(.05 / 6=.008)$ was required for significance. The results of the Pearson Correlational analysis between the decision styles and each of the measures of leadership styles are shown on Table 3 . The results revealed that no significant correlation exists between decision making styles and leadership styles of school principals.

\section{Discussion}

The present study examined the relationship between decision-making styles and leadership styles. "Directive decision making style" was predominant among school principals, with mean score 60.37 (SD, 31.82). Leadership style $(5,5)$ "Constituency-Centered Administration" was predominant among school principals, with mean score 24.25 (SD, 2.57). The results revealed that no significant correlation exists between decision making styles and leadership styles of school principals.

Directive people have low tolerance for ambiguity, a characteristic that sometimes makes one feel insecure, rigid, and incline to be aggressive. Socially, they are impersonal, and do not socialize well. Exposed to stressful events such persons can yield to anger, antagonism and rage (Rowe and Mason, 1987; Rowe, Boulgarides, and McGrath, 1984). It is not surprising that those characterized with directive style will show low level of hardiness.

It is important to point out that the correlation were not as predicted, and were not significant. Other than the small sample of the participants in each of the four styles, it is difficult to explain the absence of results in expected direction. It is possible, however, that the six leadership styles selected for the present study are not the ones that affected decision making. It is possible that one cannot characterize the different decision styles by having different relationships with either the different types of leadership styles.

One of the obvious limitations of the present study is the small number of persons classified in each decision-making style as judge by the dominant scores. This fact adversely affects the chances to obtain significant correlation coefficients. Therefore; in future research, it is recommended to increase the participants' number in the study.

In conclusion, the rather incidental findings regarding the relationship between decision making styles and leadership styles are fascinating. They lend credence to the concept of leadership and may serve as an additional support to its concurrent validity. Regarding leadership and decision styles more studies are needed. A good idea might be narrowing the study by limiting the population of participants in the study (e.g. gender, education level, executives, managers, employees, etc.). It is logical to assume that being aware of one's decision style, as well as leadership styles, may help to focus on achieving the organization objectives, develops necessary skills, and deals in a better way with a given situation such as problem solving, motivating and interacting with others. 
An open door policy and principal accessibility and approachability are important, particularly to staff and students, but this may come at a price in terms of the principal's capacity to deal with a heavy workload. Hands on leadership and attention to detail are also important, but need to be balanced with preparedness to delegate to others and to encourage and recognize the performance of delegated functions.

\section{References}

Alker, H. N., Rao, V. R., \& Hughes, G. D. (1972). Value consistent and expedient decision making. American Psychological Association Proceeding, 7, 149-150.

AL-OMARI, A., Al-Shudaifat, S., \& Abu Naba'h, A. (2008). Perceived leadership styles of principals and its relation to teachers' burnout in public schools in Jordan. Jordan Journal of Educational Sciences, 2(4), 105-114.

Bianco, W. T. (1984). Strategic decisions on candidacy in U.S. congressional districts. Legislative Studies Quarterly, 9, 351-364. http://dx.doi.org/10.2307/439396

Blake, R. R., \& Mouton, J. S. (1978). Should you teach there's only one best way to manage? Training, 15(4), 24-27.

Blake, R. R., \& Mouton, J. S. (1985). The managerial grid III (3rd ed.). Houston: Gulf.

Blake, R. R., Mouton, J. S., \& Williams, M. S. (1981). The academic administrator grid. San Francisco: Jossey-Bass.

Boulgarides, D. J., \& Cohen. W. A. (2001). Leadership style vs. leadership tactics. Journal of Applied Management and Entrepreneurship, 6, 59-73.

Burke, W. W. (1982). Organization development: Principles and practices. Boston: Little, Brown.

Connor, P. E., \& Becker, R. W. (2003). Personal value system and decision-making styles of public managers. Public personal management, 32, 155-180.

Darwazah, A. (2003). To what extent does the school principal taking decisions for improving his/ her schools? Arab Universities Association Journal, 41, 5-40.

Dorff, R. H., \& Steiner. J. (1981). Political decision making in face to face groups: Theory, methods, and an empirical application in Switzerland. The American Political Science Review, 75, 368-380. http://dx.doi.org/10.2307/1961371

Drath, W. H., \& Palus, C. J. (1994). Making common sense: Leadership as meaning-making in a community of practice. Greensboro, NC: Center for Creative Leadership.

Fiedler, F. E. (1967). A theory of leadership effectiveness. New York: McGraw-Hill.

Gelatt, H. B. (1962). Decision making: A conceptual frame of reference for counseling. Journal of Counseling Psychology, 9, 240-245. http://dx.doi.org/10.1037/h0046720

Hanson, R. A. (1970). A formal analysis of a constitutional decision making argument. Midwest Journal of Political Science, 14, 596-625. http://dx.doi.org/10.2307/2110355

Hersey, P., \& Blanchard, K. H. (1982). Management of organizational behavior: Utilizing human resources. Englewood Cliffs, NJ: Prentice-Hall.

Kouzes, J. M., \& Posner, B. Z. (2002). The leadership challenge (3rd ed.). Jossey-Bass, San Francisco, CA.

Krumboltz, J. D., \& Hamel, D. A. (1977). Guide to career decision making skills. New York: College Entrance Examination Board.

Myers, S. M. (2000). The impact of rel igious involvement on migration. Social Forces, 79, 755-783.

Phillips, S. D. (1997). Toward an expanded definition of adaptive decision making. The Career Development quarterly, 45, 275-287. http://dx.doi.org/10.1002/j.2161-0045.1997.tb00471.x

Pitz, G. F., \& Harren, V. A. (1980). An analysis of career decision making from the point of view of information processing and decision theory. Journal of Vocational Behavior, 16, 320-346. http://dx.doi.org/10.1016/0001-8791(80)90059-7

Preche1, H. (1994). Economic crisis and the centralization of control over the managerial process: Corporate restructuring and Neo-Fordist decision making. American Sociological Review, 5, 723-745. http://dx.doi.org/10.2307/2096445 
Ravlin, E. C., \& Meglino, B. M. (1987). Effect of values on perception and decision making: A study of alternative work values measures. Journal of Applied Psychology, 72, 666-673. http://dx.doi.org/10.1037/0021-9010.72.4.666

Rowe, A. J., \& Boulgarides, J. D. (1992). Managerial decision making: A guide to successful business decisions. New York: Macmillan.

Rowe, A. J., \& Davis, S. A. (1996). Intelligent information systems: Meeting the challenge of the knowledge era. Westport, CT: Quorum books.

Rowe, A. J., \& Mason, O. R. (1987). Managing with style: A guide to understanding, assessing, and improving decision making. San Francisco, CA: Jossey-Bass.

Rowe, A. J., Boulgarides, J. D., \& McGrath, M. R. (1984). Managerial decision making. Chicago, IL: Science research associates.

Schein, E. H. (1992). Organizational culture and leadership (2nd ed.). Jossey Bass, San Francisco.

Scott, S. O., \& Bruce, R. A. (1995). Decision-making style: The development and assessment of a new measure. Educational and Psychological Measurement, http://dx.doi.org/10.1177/0013164495055005017

Starmer, C. (2000). Development in non-expected utility theory: The hunt for a descriptive theory of choice under risk. Journal of economic Literature, 38, 332-382. http://dx.doi.org/10.1257/jel.38.2.332

Sturn, M. S. (1999). I just want to be fair: Interpersonal justice in intergenerational transfer of non-titled property. Family Relations, 48, 159-166. http://dx.doi.org/10.2307/585079

Thunholm, P. (2004). Decision making style: Habit, style or both. Personality and individual differences, 36 , 931-944. http://dx.doi.org/10.1016/S0191-8869(03)00162-4

Tversky, A., \& Thaler. R. H. (1990). Anomalies: Preference reversals. The Journal of Economic perspective, 4, 201-211. http://dx.doi.org/10.1257/jep.4.2.201

Valenzuela, K. (2007). Leadership definition. Retrieved July 6, 2008, from http://www.bealeader.net/be-a-leader.php

\section{Appendix A}

\section{Decision Style Inventory (DSI)}

The Decision Style Inventory consists of 20 questions organized in a table contains 5 columns. The first column represents the question and the other four columns represent a different statement. Each statement has four responses, which reflect the person's preferences. Responses can be ranked by four numbers: $1,2,4$, or $8.1=$ least preferred, $2=$ considered on occasion, $4=$ considered often, $8=$ most preferred. For each question, use the space in the boxes next to each of the answers. Please note that each number can be used only once to answer a question. Do not repeat any number when answering a given question.

The responses reflect how you feel about each statement and what you prefer to do. It is impossible to rank the same number for each response in the same row more than once, and if so you must change your response, choosing the number best representing your preference.

There is no time limit for completing the inventory, there are no wrong answers, and the order in which you answer the questions is not important.

An example of how to use the inventory and how to rank your responses in the right way:

THE WRONG ANSWER: two or more responses in one set are given same score.

\begin{tabular}{|l|l|l|l|l|l|l|l|l|}
\hline $\begin{array}{l}\text { 1. my prime } \\
\text { objective is } \\
\text { to: }\end{array}$ & $\begin{array}{l}\text { Have a position } \\
\text { with status }\end{array}$ & $\begin{array}{l}\text { Be the best in } \\
\text { my field }\end{array}$ & $\begin{array}{l}\text { Achieve recognition } \\
\text { for my work }\end{array}$ & $\begin{array}{l}\text { Feel secure I } \\
\text { my job }\end{array}$ & \\
\hline
\end{tabular}

Must be ranked differently.

THE CORRECT ANSWER: Each response in each set has different score.

\begin{tabular}{|l|l|l|l|l|l|l|l|l|}
\hline 1. my prime & Have a position & 1 & Be the best in & 4 & Achieve recognition & 2 & Feel secure I & 8 \\
\hline
\end{tabular}




\begin{tabular}{|l|l|l|l|l|l|l|l|l|}
\hline $\begin{array}{l}\text { objective is } \\
\text { to: }\end{array}$ & with status & my field & for my work & my job & \\
\hline
\end{tabular}

\begin{tabular}{|c|c|c|c|c|}
\hline $\begin{array}{l}\text { 1. my prime } \\
\text { objective is to: }\end{array}$ & $\begin{array}{l}\text { Have a position } \\
\text { with status }\end{array}$ & $\begin{array}{l}\text { Be the best in my } \\
\text { field }\end{array}$ & $\begin{array}{l}\text { Achieve recognition } \\
\text { for my work }\end{array}$ & $\begin{array}{l}\text { Feel secure I } \\
\text { my job }\end{array}$ \\
\hline 2. I enjoy jobs that: & $\begin{array}{l}\text { Are technical } \\
\text { and well defined }\end{array}$ & $\begin{array}{l}\text { Have } \\
\text { considerable } \\
\text { variety }\end{array}$ & $\begin{array}{l}\text { Allow independent } \\
\text { action }\end{array}$ & Involve people \\
\hline $\begin{array}{l}\text { 3. I expect people } \\
\text { working for me to } \\
\text { be: }\end{array}$ & $\begin{array}{l}\text { Productive and } \\
\text { fast }\end{array}$ & Highly capable & $\begin{array}{l}\text { Committed and } \\
\text { responsive }\end{array}$ & $\begin{array}{l}\text { Receptive to } \\
\text { suggestions }\end{array}$ \\
\hline $\begin{array}{l}\text { 4. In my job, I look } \\
\text { for: }\end{array}$ & Practical results & $\begin{array}{l}\text { The best } \\
\text { solutions }\end{array}$ & $\begin{array}{l}\text { New approaches or } \\
\text { ideas }\end{array}$ & $\begin{array}{l}\text { Good working } \\
\text { environment }\end{array}$ \\
\hline $\begin{array}{l}5 . \text { I communicate } \\
\text { best with others: }\end{array}$ & $\begin{array}{l}\text { On direct one to } \\
\text { one basis }\end{array}$ & In writing & $\begin{array}{l}\text { By having a group } \\
\text { discussion }\end{array}$ & $\begin{array}{l}\text { In a formal } \\
\text { meeting }\end{array}$ \\
\hline $\begin{array}{l}\text { 6. In my planning I } \\
\text { emphasize: }\end{array}$ & $\begin{array}{l}\text { Current } \\
\text { problems }\end{array}$ & $\begin{array}{l}\text { Meeting } \\
\text { objectives }\end{array}$ & Future goals & $\begin{array}{l}\text { Developing } \\
\text { people's } \\
\text { careers }\end{array}$ \\
\hline $\begin{array}{l}\text { 7. When faced with } \\
\text { solving a problem, I: }\end{array}$ & $\begin{array}{l}\text { Rely on proven } \\
\text { approaches }\end{array}$ & $\begin{array}{l}\text { Apply careful } \\
\text { analysis }\end{array}$ & $\begin{array}{l}\text { Look for creative } \\
\text { approaches }\end{array}$ & $\begin{array}{l}\text { Rely on my } \\
\text { feelings }\end{array}$ \\
\hline $\begin{array}{l}\text { 8. when using } \\
\text { information, prefer: }\end{array}$ & Specific facts & $\begin{array}{l}\text { Accurate and } \\
\text { complete data }\end{array}$ & $\begin{array}{l}\text { Broad coverage of } \\
\text { many options }\end{array}$ & $\begin{array}{l}\text { Limited data } \\
\text { that are easily } \\
\text { understood }\end{array}$ \\
\hline $\begin{array}{l}\text { 9. When I am no } \\
\text { sure about what to } \\
\text { do, I: }\end{array}$ & Rely on intuition & Search for facts & $\begin{array}{l}\text { Look for a possible } \\
\text { compromise }\end{array}$ & $\begin{array}{l}\text { Wait before } \\
\text { making a } \\
\text { decision }\end{array}$ \\
\hline $\begin{array}{l}\text { 10. Whenever } \\
\text { possible, I avoid: }\end{array}$ & Long debates & Incomplete work & $\begin{array}{l}\text { Using numbers or } \\
\text { formulas }\end{array}$ & $\begin{array}{l}\text { Conflict with } \\
\text { others }\end{array}$ \\
\hline $\begin{array}{l}\text { 11. I am especially } \\
\text { good at: }\end{array}$ & $\begin{array}{l}\text { Remembering } \\
\text { dates and facts }\end{array}$ & $\begin{array}{l}\text { Solving difficult } \\
\text { problems }\end{array}$ & $\begin{array}{l}\text { Seeing many } \\
\text { possibilities }\end{array}$ & $\begin{array}{l}\text { Interacting } \\
\text { with others }\end{array}$ \\
\hline $\begin{array}{l}\text { 12. When time is } \\
\text { important, I: }\end{array}$ & $\begin{array}{l}\text { Decide and act } \\
\text { quickly }\end{array}$ & $\begin{array}{l}\text { Follow plan and } \\
\text { priorities }\end{array}$ & $\begin{array}{l}\text { Refuse to be } \\
\text { pressured }\end{array}$ & $\begin{array}{l}\text { Seek guidance } \\
\text { or support }\end{array}$ \\
\hline $\begin{array}{l}\text { 13. In social } \\
\text { settings, in } \\
\text { generally: }\end{array}$ & $\begin{array}{l}\text { Speak with } \\
\text { others }\end{array}$ & $\begin{array}{l}\text { Think about } \\
\text { what is being } \\
\text { said }\end{array}$ & $\begin{array}{l}\text { Observe what is } \\
\text { going on }\end{array}$ & $\begin{array}{l}\text { Listen to the } \\
\text { conversation }\end{array}$ \\
\hline $\begin{array}{l}\text { 14. I am good at } \\
\text { remembering: }\end{array}$ & People's names & Places we met & People's faces & $\begin{array}{l}\text { People's } \\
\text { personalities }\end{array}$ \\
\hline $\begin{array}{l}\text { 15. The work I do } \\
\text { provides me: }\end{array}$ & $\begin{array}{l}\text { The power to } \\
\text { influence others }\end{array}$ & $\begin{array}{l}\text { Challenging } \\
\text { assignments }\end{array}$ & $\begin{array}{l}\text { Achieving my } \\
\text { personal goals }\end{array}$ & $\begin{array}{l}\text { Acceptance by } \\
\text { the group }\end{array}$ \\
\hline $\begin{array}{l}\text { 16. I work well with } \\
\text { those who are: }\end{array}$ & $\begin{array}{l}\text { Energetic and } \\
\text { ambitious }\end{array}$ & Self-confident & Open-minded & $\begin{array}{l}\text { Polite and } \\
\text { trusting }\end{array}$ \\
\hline $\begin{array}{l}\text { 17. When I under } \\
\text { stress, I: }\end{array}$ & Become anxious & $\begin{array}{l}\text { Concentrate on } \\
\text { the problem }\end{array}$ & Become frustrated & Am forgetful \\
\hline $\begin{array}{l}\text { 18. Others consider } \\
\text { me: }\end{array}$ & Aggressive & Disciplined & Imaginative & Supportive \\
\hline $\begin{array}{l}\text { 19. My decisions } \\
\text { typically are: }\end{array}$ & $\begin{array}{l}\text { Realistic and } \\
\text { direct }\end{array}$ & $\begin{array}{l}\text { Systematic or } \\
\text { abstract }\end{array}$ & Broad and flexible & $\begin{array}{l}\text { Sensitive to } \\
\text { the needs of } \\
\text { others }\end{array}$ \\
\hline
\end{tabular}




\begin{tabular}{|l|l|l|l|l|l|l|l|l|}
\hline 20. I dislike: & Losing control & & Boring work & & Following rules & & Being rejected & \\
\hline Total Scores: & & & & & & & & \\
\hline
\end{tabular}

\section{Typical Range of Style Scores}

\begin{tabular}{lcccc} 
Least Preferred & Backup & Dominant & \multicolumn{2}{c}{ Very Dominant } \\
Directive & $20-67$ & $68-81$ & $82-89$ & $90-160$ \\
Analytical & $20-82$ & $83-96$ & $97-104$ & $105-160$ \\
Conceptual & $20-72$ & $73-86$ & $87-94$ & $95-160$ \\
Behavioral & $20-47$ & $48-61$ & $62-69$ & $70-160$ \\
Appendix B & & & &
\end{tabular}

\section{Administrative Styles Questionnaire}

\section{Self Assessment}

Six areas of leadership are identified in this questionnaire. In each area are statements, which describe various styles of leadership. Please read all of the statements and then rank each statement from 1-6 with 6 being your preferred style, 5 being your second most preferred style, 4 being your third most preferred style, 3 being your fourth most preferred style, 2 being your fifth most preferred style, and 1 being your least preferred leadership style. Each statement must be ranked differently. There can be no duplicate ranks.

\section{Area 1: INITIATIVE,}

( ) 1- I initiates actions that help and support others.

( ) 2- I put out enough to get by.

( ) 3- I drive myself and others.

( ) 4- I seek to maintain a steady pace.

( ) 5- I exert vigorous effort and cause others to join in enthusiastically.

( ) 6- I stress loyalty and extend appreciation to those who support his/ her initiatives.

\section{Area 2: INQUIRY}

( ) 7- I double-check what others tell him/ her and compliment them when I am able to verify their position.

( ) 8- I investigate the facts and positions so that he/ she is in control of any situation and to assure that others are not making mistakes.

( ) 9- I invite and listen for opinions and ideas different from my own. Continuously re-evaluates his/ her facts, beliefs, and positions.

( ) 10- I take things at face value and check facts and positions when obvious discrepancies appear.

( ) 11- I look for facts and positions that suggest all is well. Prefer harmony to challenge.

( ) 12-I go along with facts and opinions given him.

\section{Area 3: ADVOCACY}

( ) 13- I keep my own position and avoid taking sides by revealing true opinions or ideas.

( ) 14- I maintain strong convictions but permit others to express their ideas so that I can help them think more objectively.

( ) 15- I take the opinions and ideas of others even though I may have reservations.

( ) 16-I feel it is important to express his/ her convictions and respond to sound ideas by changing my mind.

( ) 17- I express opinions and ideas in a tentative way and try to meet others halfway.

( ) 18-I stand up for my opinions and ideas even though it means rejecting the views of others. 


\section{Area 4: CONFLICT}

( ) 19- I try to cut it off or win my position.

( ) 20- I try to find a position that others find suitable.

( ) 21- I try to soothe feelings to keep people together.

( ) 22- I seek reasons for it in order to resolve the underlying causes.

( ) 23- I terminate it but thank people for expressing their views.

( ) 24- I remain neutral or seek to stay out of conflict.

\section{Area 5: MAKING DECSIONS}

( ) 25- I have the last say and make a sincere effort to see that his/ her decisions are accepted.

( ) 26- I place a high value on making my own decisions and rarely is influenced by others.

( ) 27-I place a high value on arriving at sound decisions based on understanding and agreement.

( ) 28-I allow others to make decisions or come to terms with whatever happens.

( ) 29- I look for decisions that maintain good relations and encourage others to make decisions.

( ) 30- I search for workable decisions that others will accept.

\section{Area 6: CRITIQUE}

( ) 31-I encourage two-way feedback to strengthen operations.

( ) 32-I give informal feedback regarding suggestions for improvement.

( ) 33- I identify weaknesses in my staff.

( ) 34- I avoid giving feedback.

( ) 35- I give others feedback and expect them to accept it because it is for their own good.

( ) 36- I encourage and praise when something positive happens, but avoid giving negative comments.

\section{Copyrights}

Copyright for this article is retained by the author(s), with first publication rights granted to the journal.

This is an open-access article distributed under the terms and conditions of the Creative Commons Attribution license (http://creativecommons.org/licenses/by/3.0/). 